\title{
Comparative susceptibility of two races of Salmo salar (Baltic Lule river and Atlantic Conon river strains) to infection with Gyrodactylus salaris
}

\author{
M. B. Dalgaard*, C. V. Nielsen, K. Buchmann \\ Department of Veterinary Microbiology, Section of Fish Diseases, Royal Veterinary and Agricultural University, 4 Stigbøjlen, \\ 1870 Frederiksberg Centrum, Denmark
}

\begin{abstract}
The susceptibility of various races of salmonids towards infections with the skin parasitic monogenean Gyrodactylus salaris Malmberg, 1957, differs markedly. Norwegian and Scottish salmon strains are known as extremely susceptible to infection, whereas Baltic salmon races such as the Neva strain (Russian origin) and the Indals river (Swedish origin) salmon have been characterized as relatively resistant. However, the status of the many other Baltic strains has remained unknown. The present study reports on the susceptibility of the Baltic salmon from the Swedish river Lule. It was shown that this strain is susceptible to infection but to a lesser extent than the Scottish salmon. Further studies showed that injection of immuno-suppressants (dexamethasone) greatly increased population growth of G. salaris on Scottish salmon but not on the Baltic salmon. Mucous cell density on fins differed between strains, and a general trend to decreased cell density on infected fish $8 \mathrm{wk}$ post-infection, compared to uninfected fish, was observed. The largest decrease in mucous cell density following infection was seen in the most resistant fish. After administration of immuno-suppressants, this decrease in mucous cell density was inhibited in the Scottish salmon but not in the Baltic salmon. Thus, there seems to be a relationship between the fishes' ability to discard mucous cells and the ability to resist infections with Gyrodactylus salaris. Although the Lule salmon seems more susceptible to infection compared to previous reports on the Neva salmon, the results support the notion that Baltic salmon strains are generally more resistant than East Atlantic salmon.
\end{abstract}

KEY WORDS: Atlantic salmon - Salmo salar - Conon river · Lule river · Gyrodactylus salaris · Susceptibility · Mucous cells · Dexamethasone

Resale or republication not permitted without written consent of the publisher

The skin parasitic monogenean Gyrodactylus salaris Malmberg, 1957, has devastated Norwegian salmon stocks due to the extreme susceptibility of this salmon race (Johnsen \& Jensen 1991, Mo 1994) to infection. Studies have shown that Scottish strains of the Atlantic salmon are quite susceptible as well (Bakke \& MacKenzie 1993). In contrast, salmon from the Russian Neva river draining into the Baltic are known to be relatively resistant (Bakke et al. 1990). Likewise, the Baltic salmon from the Indals river are also less susceptible (Bakke et al. 2002). This follows the hypothesis that the parasite has been present in the Baltic region since the last glacial period and has exerted heavy selection pressure on the local salmon race (Bakke et al. 2002). However, the Baltic salmon race comprises a vast number of different strains homing to different rivers (Nilsson et al. 2001), and the susceptibility status of these, except the Neva and Indals river strains, has not been reported. Therefore we have conducted a comparative study on the susceptibility to infection with G. salaris of Baltic salmon from the Lule river and Atlantic salmon from the Scottish river Conon.

Materials and methods. Fish: Scottish salmon: Eyed eggs of the Scottish strain from the Conon river were purchased from the Danish hatchery DVC-Randers in Jutland (western part of Denmark). Fish were subsequently transported to our laboratory at the Royal Veterinary and Agricultural University (KVL) and used for infection experiments 6 mo post-hatching. The Conon river salmon had a body length of between 7.8 and $8.9 \mathrm{~cm}$ and a body weight of between 8.1 and $8.4 \mathrm{~g}$.

Baltic salmon: Eyed eggs of the Baltic strain were obtained from the Swedish hatchery (Vattenfall, Luleå, northern Sweden). Eggs of both strains were brought to the Bornholm salmon hatchery (Nexø, Bornholm), where hatching and rearing of larvae were conducted under pathogen-free conditions in recirculated freshwater. Fish were subsequently transported to our laboratory at the Royal Veterinary and Agricultural University (KVL) and used for infection experiments 6 mo post-hatching. The corresponding length of the Lule river salmon was between 9.5 and $10.1 \mathrm{~cm}$ with a body weight ranging between 10.2 and $10.7 \mathrm{~g}$. 
Parasites: Gyrodactylus salaris on Norwegian salmon collected in the river Lærdalselva in Norway were brought to our laboratory at Frederiksberg, Denmark and used for the establishment of a laboratory population on Scottish Conon salmon kept in 2001 aquaria at $13^{\circ} \mathrm{C}$.

Corticosteroid treatment of fish: Individual fish from each strain were injected intra-peritoneally with $0.1 \mathrm{ml}$ Dexadresone (dexamethasone $2 \mathrm{mg} \mathrm{ml}^{-1}$ ) corresponding to $200 \mu \mathrm{g}$ dexamethasone per fish. Injected salmon were kept $48 \mathrm{~h}$ before the initiation of the infection.

Water: Fish and parasites were kept in a mixture of $50 \%$ dechlorinated municipal water and $50 \%$ de-ionized water with a final calcium carbonate hardness of $200 \mathrm{mg} \mathrm{l}^{-1}$. Temperature was $13^{\circ} \mathrm{C}$ and $\mathrm{pH}$ 7.0. Water was continuously aerated and treated with an internal biofilter (Eheim) eliminating nitrite and ammonia.

Experimental design: The different fish groups were exposed together to infection with Gyrodactylus salaris in a 2001 aquarium. Thus, 5 untreated Conon and 10 untreated Lule river salmon were stocked with 5 dexamethasone treated Conon and 10 dexamethasone treated Lule salmon. Fish were differentiated by finclipping. Infection was achieved by cohabitation with 6 Conon salmon infected with a total of 386 parasites. Parasites from the infected donor fish were allowed to spread to the experimental fish during the following experimental period.

Parasite counting: The number of parasites present on various body parts and fins of MS222- $\left(50 \mathrm{mg} \mathrm{l}^{-1}\right)$ anaesthetized salmon were counted under the dissection microscope ( 7 to $40 \times$ magnification) according to Buchmann \& Uldal (1997). Parasites were counted once a week.

Mucous cell counting: At the end of the experiment, $8 \mathrm{wk}$ post-infection, tail fins from fish in the various groups including uninfected controls were formalin-fixed and stained with $1 \%$ Alcian Blue in 3\% acetic acid (Buchmann \& Uldal 1997). Following mounting in Aquamount, the number of superficial mucous cells were counted (blinded) in a light microscope on an area of $0.75 \mathrm{~mm}^{2}$ (3 zones of $0.25^{2} \mathrm{~mm}$ caudal-anterior direction) on each fin (200× magnification).

Statistics: Infection levels were expressed as prevalence (percentage of hosts infected) and mean intensity (mean number of parasites per infected fish) according to Bush et al. (1997). Differences of means between groups were evaluated with the Tukey test with a probability level of 0.05 .
Results and discussion. All fish became infected and kept the parasites throughout the experimental period of $8 \mathrm{wk}$. The Gyrodactylus salaris population increased significantly more on Conon salmon (mean intensity 98 parasites per fish in Week 8) compared to Lule salmon (mean intensity 35 parasites per fish). In addition, the dexamethasone treated Scottish salmon experienced an even higher infection level within the period (mean intensity 280 parasites per fish). In contrast, corticosteroid treatment of Lule salmon resulted in only slightly larger parasite populations compared to untreated Lule river salmon. Thus, treated Lule salmon harboured a mean of 40,36 and 33 parasites in Weeks 6,7 and 8, respectively, compared to 32,22 and 35 parasites in untreated fish (Table 1). Some mortality was seen during the experiment (Table 1). Mucous cell densities varied between groups. In Week 8, untreated and uninfected Conon salmon had a higher number of mucous cells per unit area compared to corresponding Lule salmon. When untreated fish became infected, the mucous cell density decreased markedly within 8 wk (both salmon strains). This was also seen in dexamethasone-treated Lule salmon but not in treated Conon salmon, which did not show a decrease of mucous cell density following infection (Table 2).

The present investigation indicated that the Baltic Lule strain is more resistant, compared to the Scottish Conon salmon, to infection with the Norwegian Lærdalselva strain of Gyrodactylus salaris. This is in line with the notion that the Baltic salmon has coexisted with this monogenean for an extended time period whereby a relative resistance of the host could

Table 1. Mean intensity (MI) standard deviation $( \pm \mathrm{SD})$ and mortality $(\mathrm{M} \%)$ of salmon groups during the 8 wk infection experiment. A, B, C, D, E, G: significantly different $(p<0.05)$ in relation to corticosteroid treated Conon salmon. F: significantly different $(\mathrm{p}<0.05)$ in relation to untreated Conon salmon

\begin{tabular}{|c|c|c|c|c|c|c|c|c|}
\hline & 0 & 1 & 3 & 4 & 5 & 6 & 7 & 8 \\
\hline \multicolumn{9}{|c|}{ Conon salmon untreated } \\
\hline MI & 0 & 3.8 & 17.2 & 22.4 & 27.0 & 59.5 & 71.0 & 98.0 \\
\hline (SD) & $(0)$ & $(1.5)$ & $(4.1)$ & $(5.8) \mathrm{B}$ & $(10.1) \mathrm{C}$ & $(16.7) \mathrm{D}$ & (32.0) E & (34.6) G \\
\hline M\% & 0 & 0 & 0 & 0 & 20 & 20 & 40 & 40 \\
\hline \multicolumn{9}{|c|}{ Conon salmon treated } \\
\hline MI & 0 & 5.7 & 31.3 & 47.0 & 56.5 & 162.0 & 128.7 & 279.7 \\
\hline (SD) & $(0)$ & $(4.2)$ & $(17.5)$ & $(10.4)$ & (8.6) & $(40.6)$ & $(14.2)$ & (65.5) \\
\hline M\% & 0 & 20 & 20 & 20 & 20 & 20 & 40 & 40 \\
\hline \multicolumn{9}{|c|}{ Lule salmon untreated } \\
\hline MI & 0 & 4.1 & 9.8 & 17.0 & 19.7 & 32.7 & 22.4 & 35.3 \\
\hline (SD) & $(0)$ & $(3.8)$ & (5.3) A & $(11.5) \mathrm{B}$ & $(10.5) \mathrm{C}$ & (20.9) D & $(15.2) \mathrm{E}, \mathrm{F}$ & $(31.8) \mathrm{G}$ \\
\hline M\% & 0 & 0 & 10 & 10 & 10 & 10 & 10 & 20 \\
\hline \multicolumn{9}{|c|}{ Lule salmon treated } \\
\hline MI & 0 & 3.0 & 21.5 & 21.9 & 27.6 & 39.9 & 36.1 & 32.8 \\
\hline (SD) & $(0)$ & $(1.4)$ & $(9.2)$ & (9.6) B & $(11.6) \mathrm{C}$ & (19.8) D & $(20.7) \mathrm{E}$ & $(17.4) \mathrm{G}$ \\
\hline M\% & 0 & 10 & 10 & 10 & 20 & 20 & 30 & 40 \\
\hline
\end{tabular}


Table 2. Mucous cell number (mean $\pm \mathrm{SD}$ ) on $0.75 \mathrm{~mm}$ caudal fin from different salmon groups. A: significantly different ( $p$ $<0.05$ ) in relation to untreated and uninfected Conon salmon. B: significantly different $(\mathrm{p}<0.05)$ in relation to treated and infected Conon salmon

\begin{tabular}{|lcc|}
\hline & $\begin{array}{c}\text { No. } \\
\text { of fish }\end{array}$ & $\begin{array}{c}\text { Mucous cell no. } \\
\text { (mean } \pm \text { SD) }\end{array}$ \\
\hline $\begin{array}{l}\text { Conon salmon } \\
\text { Untreated and uninfected } \\
\text { Lule salmon }\end{array}$ & 4 & $610(109)$ \\
$\begin{array}{l}\text { Untreated and uninfected } \\
\text { Conon salmon }\end{array}$ & 4 & $376(74)$ \\
$\begin{array}{l}\text { Untreated and infected } \\
\text { Lule salmon }\end{array}$ & 4 & $419(141)$ \\
$\begin{array}{l}\text { Untreated and infected } \\
\text { Conon salmon }\end{array}$ & 2 & $217(68)$ \\
$\begin{array}{l}\text { Treated and infected } \\
\text { Lule salmon } \\
\text { Treated and infected }\end{array}$ & 3 & $\begin{array}{c}\text { A, B } \\
\text { (207) }\end{array}$ \\
\hline
\end{tabular}

have been selected (Bakke et al. 2002). In contrast, the Scottish salmon has never been exposed to this pathogen and has not evolved resistance. The susceptibility of the Scottish salmon is in accordance with previous results obtained by Bakke \& MacKenzie (1993). No information about the Lule salmon susceptibility has been presented previously. However, our results point to a relative resistance which can be compared with other Baltic salmon strains. The Neva strain has been shown to respond after less than $30 \mathrm{~d}$ postinfection at a peak infection intensity of less than 150 parasites; the other tested Baltic salmon from the Indals river responded within 40 d (Bakke et al. 2002). Lule salmon did not show higher intensities than this but the low peak occurred after $6 \mathrm{wk}$, which is delayed compared to the other Baltic salmon. The mechanisms involved in resistance of salmonids against infections with gyrodactylids are not clearly described (Buchmann \& Lindenstrøm 2002). However, a number of studies have indicated that the fish immune responses play a role. Thus, Gyrodactylid infection elicits cytokine expression in fish skin (Lindenstrøm et al. 2003) whereby a number of immunological reactions are initiated. It has also been described that complementfactors from salmonids bind to and kill gyrodactylids (Buchmann 1998, Harris et al. 1998), and the level of complement-factor expression during infection is increased in Neva salmon compared to Norwegian salmon (Bakke et al. 2002). Furthermore, host macrophages colonize and kill gyrodactylids in vitro (Buchmann \& Bresciani 1999) and dexamethasone significantly down-regulates macrophage activity (Pagniello et al. 2002). In addition, other immunosuppressants, such as hydrocortisone (Harris et al. 2000), have been shown to inhibit the host resistance towards infection with specific gyrodactylids, which further suggests the role of immune factors in host specificity. However, the effects of corticosteroids on mammals are quite complex (Wilckens \& De Rijk 1997) and it cannot be excluded that other mechanisms in fish might be affected by the steroid treatment.

Mucous cell densities have previously been suggested to influence behaviour and survival of gyrodactylids on rainbow trout skin (Buchmann \& Bresciani 1998). It was indicated that parasites select mucous cell rich areas during initial colonization but escape these spots during the host response phase. In the present experiment, the most susceptible salmon (Conon) showed a higher density of mucous cells than Lule salmon (Table 2). When infected for $8 \mathrm{wk}$, both salmon races exhibited a decrease of mucous cell densities of their tail fins. Furthermore, dexamethasone treatment seemed to inhibit the mucous cell discharge of infected Conon salmon concomitant with an extensive parasite colonization. This was not seen in Lule salmon, which only permitted a low parasitization. These observations justify further studies on the role of mucous cell dynamics in host response and host specificity.

Acknowledgements. The authors are indebted to Dr. Tor Atle Mo, National Veterinary Institute, Norway, for providing parasite material. This study was conducted in association with the EU-project 'The genetic basis of Gyrodactylus salaris resistance in atlantic salmon, Salmo salar' (QLRT 2000-01631) and further supported by a grant from the Danish Agricultural and Veterinary Research Council and the Ministry of Food, Agriculture and Fisheries to the research network SCOFDA (Sustainable Control of Fish Diseases in Aquaculture). The skilled management of fry by Jim Hee and John Haakonson in the salmon hatchery before experimentation is greatly acknowledged.

\section{LITERATURE CITED}

Bakke TA, MacKenzie K (1993) Comparative susceptibility of native Scottish and Norwegian stocks of Atlantic salmon, Salmo salar L., to Gyrodactylus salaris Malmberg: laboratory experiments. Fish Res 17:69-85

Bakke TA, Jansen PA, Hansen LP (1990) Differences in the host resistance of Atlantic salmon, Salmo salar L., stocks to the monogenean Gyrodactylus salaris Malmberg, 1957. J Fish Biol 37:577-587

Bakke TA, Harris PD, Cable J (2002) Host specificity dynamics: observations on gyrodactylid monogeneans. Int J Parasitol 32:281-308

Buchmann K (1998) Binding and lethal effect of complement from Oncorhynchus mykiss on Gyrodactylus derjavini (Platyhelminthes: Monogenea). Dis Aquat Org 32: 195-200

Buchmann K, Bresciani J (1998) Microenvironment of Gyrodactylus derjavini on rainbow trout Oncorhynchus mykiss: association between mucous cell density in skin and site selection. Parasitol Res 84:17-24

Buchmann K, Bresciani J (1999) Rainbow trout leucocyte activity: influence on the ectoparasitic monogenean Gyrodactylus derjavini. Dis Aquat Org 35:13-22 
Buchmann K, Lindenstrøm T (2002) Interactions between monogenean parasites and their fish hosts. Int $\mathrm{J}$ Parasitol 32:309-319

Buchmann K, Uldal A (1997) Gyrodactylus derjavini infections in four salmonids: comparative host susceptibility and site selection of parasites. Dis Aquat Org 28:201-209

Bush AO, Lafferty KD, Lotz JM, Shostak AW (1997) Parasitology meets ecology on its own terms: Margolis et al. revisited. J Parasitol 83:575-583

Harris PD, Soleng A, Bakke TA (1998) Killing of Gyrodactylus salaris (Platyhelminthes, Monogenea) mediated by host complement. Parasitology 117:137-143

Harris PD, Soleng A, Bakke TA (2000) Increased susceptibility of salmonids following administration of hydrocortisone acetate. Parasitology 120:57-64

Johnsen BO, Jensen AJ (1991) The Gyrodactylus history in Norway. Aquaculture 98:289-302

Editorial responsibility: Wolfgang Körting,

Hannover, Germany
Lindenstrøm T, Buchmann K, Secombes CJ (2003) Gyrodactylus derjavini infections elicits IL- $\beta$ expression in rainbow trout skin. Fish Shellfish Immuno (in press)

Mo TA (1994) Status of Gyrodactylus salaris problems and research in Norway. In: Pike AW, Lewis JW (eds) Parasitic diseases of fish. Samara Publishing, London, p 43-58

Nilsson J, Gross R, Asplund T, Dove O and 12 others (2001) Matrilinear phylogeography of Atlantic salmon (Salmo salar L.) in Europe and postglacial colonization of the Baltic sea area. Mol Ecol 10:89-102

Pagniello KB, Bols NC, Lee LEJ (2002) Effect of corticosteroids on viability and proliferation of the rainbow trout monocyte/macrophage cell line, RTS11. Fish Shellfish Immunol 13:199-214

Wilckens T, De Rijk R (1997) Glucocorticoids and immune function: unknown dimensions and new frontiers. Immunol Today 18:418-424

Submitted: June 10, 2002; Accepted: November 19, 2002 Proofs received from author(s): January 8, 2003 